\title{
Risk Management in Project Networks: An Information Processing View
}

\author{
Leena Pekkinen, Kirsi Aaltonen \\ Industrial Engineering and Management, University of Oulu, Oulu, Finland \\ Email: leena.pekkinen@pp1.inet.fi, Kirsi.aaltonen@oulu.fi
}

Received 7 November 2014; accepted 6 February 2015; published 9 February 2015

Copyright $@ 2015$ by authors and Scientific Research Publishing Inc.

This work is licensed under the Creative Commons Attribution International License (CC BY). http://creativecommons.org/licenses/by/4.0/

(c) (i) Open Access

\begin{abstract}
Increasingly, projects are executed by networks of organizations. The networked form of organization has many important implications for project risk management. Information processing theories introduce mechanisms for processing information inside organizations as well as among organizations to reduce the uncertainty and equivocality inherently present in international projects. This study aims to examine the risk management practices involved at a project network level through an empirical analysis of one complex large project network executed in a challenging institutional environment. With regard to network level risk management, the paper identifies eight formal information processing mechanisms for implementing risk management: (1) established rules and criteria for the selection of subcontractors at a global level, (2) specification of responsibilities in the contract, (3) formal risk sheet, (4) progress follow-up tool, (5) database for project information, (6) customer reporting system, (7) updated project plan after the project is delayed, and (8) country study team. Personal relationships between parties, personal commitment, experienced individuals, and face-to-face meetings are identified as informal information processing mechanisms used as measures of project risk management to reduce equivocality. We also elaborate the fitness of the mechanisms used for the contextual situations of the project network settings.
\end{abstract}

\section{Keywords}

Risk Management, Project Network, Information Processing Theory, Uncertainty, Equivocality

\section{Introduction}

Project risk management nowadays has an acknowledged role as one of the key processes and research fields of project management [1] [2]. Recent project management studies have also emphasized the networked nature of 
projects and argued that more attention should be paid to the study of projects as intra- or inter-organizational networks [3]-[6]. Despite the central role of risk management and project networks in project management research, only limited attention has been paid to risk management in a networked project setting. The networked form of organizing has many fundamental implications for project risk management; the heterogeneous actors in project networks have oftentimes contradictory and conflicting objectives which pose fundamental coordination and integration challenges [7]-[10]. Therefore, a broader perspective on managing the risks involved in networked projects and improving risk management related co-operation and integration over organizational boundaries within the project network is needed. In the context of international networked projects, the diverse backgrounds and objectives of different actors pose fundamental challenges for effective and efficient risk management. In order for risk management to be successful, instead of focusing on the activities of individual actors, risk management activities should be integrated at a project network level [11].

In this research, an information processing view [12] is adopted to examine how risk management is carried out in a complex, international project network. The aim of this study is to identify the different types of information processing mechanisms that are used for implementing project risk management. Furthermore, we analyse how these identified mechanisms support the execution of risk management and what kinds of challenges are related to their use in a large networked project executed in a challenging environment. The analysis of the information processing mechanisms and their suitability for risk management in a networked setting draws from the literature on project risk management, project networks and information processing.

The paper is structured as follows. In the literature review section, research on project risk management, risk management in project networks, and the information processing view of risk management is reviewed. The next section introduces the research method and context. The empirical findings present the identified mechanisms for implementing risk management at the project network level. Finally, we discuss the findings in the light of the existing project risk management literature and summarize the contributions of the study.

\section{Literature Review}

\subsection{Project Risk Management}

Project risk management nowadays has been recognized to have an important role as one of the project key processes. Furthermore, project risk management is a widely researched topic in the area of project management research [1] [2] [10] [13] [14]. Prior research on project risk management has primarily focused on the concept of project risk as well as on the identification of risk sources and effective managerial approaches and tools for reducing the risks involved in projects [1] [15].

There has been a long-running debate concerning the definition of risk in the context of project management and, in particular, the term's relationship with the concept of uncertainty [2] [15] [16]. In the project management literature, the term "risk" is most often defined as the possibility that events as well as their resulting impacts and dynamic interactions may turn out differently than anticipated [2] [15] [17]. Similarly, according to the Project Management Body of Knowledge (that is the acknowledged project management standard), risk is an uncertain event or condition that, if it occurs, will have a positive or negative effect on at least one project objective [18] [19]. In this definition, both threats and opportunities are present. Traditionally, the emphasis of risk assessment has been on threats rather than opportunities [15]. Various studies have presented informed classifications of the sources of risks [10] [13] [15]. Whilst most of these studies have focused on the categorization of project risk sources in a single actor project context, a few studies have addressed risk sources in networked multi-actor projects [11] [13] [20]-[22].

The linear, rational and planning-oriented view of projects and their management is also reflected in the existing project risk management applications and structured process guidelines. In an ideal process, risks themselves as well as their probabilities and impacts, should be explicitly identified and estimated and decisions concerning appropriate responses, monitoring and control principles should be documented [1] [18] [19]. Actually, the whole planning oriented project management approach can be considered as a fundamental approach for reducing uncertainty in projects. Through detailed planning and the use of specific project management methods and tools, risks and uncertainties in projects are considered to be minimized and so better managed [9]. Accordingly, the well-known formal risk management processes and standards [1] [18] [19] typically consist of a generic process description including three core project risk management processes: risk identification, risk evaluation and risk response planning [13]. Furthermore, within the current view of project management as a 
lifecycle process, project risk management is seen as an encompassing process, starting at project definition and continuing through the planning, execution and control phases up to completion and closure [23]. All changes made to the project execution plan and changes in the ambient circumstances are sources of new risks and, therefore, continuous monitoring of the environment is required.

\subsection{Risk Management in Project Networks}

Increasingly, projects are executed by networks of organizations [3] [6] [8] [20]. Even though interrelationships are an important new area of interest, there has been very little discussion on the functioning and dynamics of project networks outside the field of project marketing [24]. Hellgren and Stjernberg [8] suggest that studies of collaborative arrangements and networks usually concern long-term inter-organizational arrangements, such as acquisitions and joint ventures. Project networks consist of relationships between actors or organizations intended to establish robust capabilities to perform the necessary tasks to achieve the set targets of the project [8]. Consequently, project networks are intentionally developed networks - they are formed in order to create capital assets for the buyer over a certain period of time [25]. Project networks can therefore be seen as an instrument of achieving specific, pre-defined targets. At a casual glance, it may appear that this common target acts as the temporary underlying force which glues the project network actors together and that it is the raison d'être of the project network [8]. Nevertheless, the individual actors involved in the temporary project network might have rationales and motivations for their participation other than completing specific short-term tasks. Consequently, the heterogeneous actors in project networks have oftentimes contradictory and conflicting objectives, which pose fundamental coordination and integration challenges in the project network [7] [9]. In such networked projects, the role of effective risk management is emphasized as being critical to the success of the project.

The networked form of organization has many important implications for project risk management. In particular, the literature on large projects identifies various major challenges and provides suggestions on organizing and managing a project enterprise as a network of several participating organizations, especially in terms of analyzing risk, uncertainty and success issues [7] [26] [27]. Firstly, the network structure in itself poses new types of risks. The multiplicity of the project actors, as well as the interactions and relations between the actors, are a source of uncertainty in the project network. Risk in the network context can be defined as an uncertain event or condition that results from the network form of work and has an impact that contradicts the expectations. The event is at least partially related to other actors in the network [13]. In other words, risks in project networks are due to relationships and interactions between parties to the project network [20]. The literature has addressed, at least to a limited extent, the sources of risks in networked project settings [13] [20]-[22] [27] [28]. Indeed, the majority of the existing studies have focused on the nature of relationships of project network actors as a risk sources. However, Ward [22] states that the involvement of multiple actors in the execution of a project introduces uncertainty arising from the ambiguity related to the following five aspects: specification of responsibilities, perceptions of roles and responsibilities, communication across interfaces, the capability of parties, and contractual conditions and their effects.

Furthermore, the networked project setting highlights the importance of a broader perspective on risk management. Complex delivery projects are typically networked efforts where the traditional single company oriented risk management approach can be considered to result in solutions that are too limited [20]. Instead of focusing on single actors in order for risk management to be successful, risk management activities should be integrated at a project network level [11] [20]. Therefore, a broader perspective concerned with managing the risks in networked projects and also improving risk-related co-operation within the project networks is needed. In particular, co-operation and integration over organizational boundaries are required in project networks in order to ensure an efficient and effective risk management approach. According to Kähkönen and Artto [13], taking into account the dynamism of the project, interactions, interrelations as well as continuous risk register updating and the scanning of an environment should be emphasized in the risk management approach in project networks. However, the current risk management literature does not fully appreciate the complexity and dynamism of the whole network of project actors.

\subsection{Information Processing View of Risk Management}

Integration techniques and coordination mechanisms have been suggested by many scholars [12] [29]-[36]. Information processing theories introduce integration and coordination mechanisms for organizations to reduce 
uncertainty and equivocality caused by technology, interdepartmental relations and environment [12] [30] [32]. In the information processing literature, uncertainty is understood as a lack of information and equivocality as ambiguity, the existence of multiple and conflicting interpretations. Information processing theories introduce formal, impersonal tools and practices to reduce uncertainty in organizations and informal, subtle procedures based on personal contacts to reduce equivocality in the organizations.

Daft and Lengel [12] propose seven structural mechanisms to fit along a continuum with respect to organizations' capacity for reducing uncertainty or for reducing equivocality. The structural mechanisms are: group meetings, integrators, direct contact, planning, special reports, formal information systems, and rules and regulations. First information processing mechanisms are relevant in cases where organizations confront high equivocality and the later mechanisms are relevant for cases where an environment of organizations is experiencing high uncertainty as a prevailing attribute. Group meetings are face-to-face meetings where participants can exchange opinions and managers can converge on the meaning of equivocal cues and so are able to enact or define solutions. Group meetings as a means of coordination enhance equivocality reduction rather than information processing capability. The integrators' role includes the transmission of data, but it is primarily a way to overcome disagreement and thereby reduce equivocality about goals, the interpretation of issues, or a course of action. Direct contact is the simplest form of personal information processing. Through discussion and exchange of viewpoints, equivocality is reduced. Planning is a dynamic process with elements of both equivocality and uncertainty reduction. The initial planning reduces equivocality while plans, schedules and feedback provide data for uncertainty reduction. Special reports include studies and surveys primarily designed to obtain data, interpret it, and thereby reduce uncertainty. Special reports tend to be undertaken for issues about which objective data is not currently available but that can be obtained through a systematic investigation and analysis. Formal information systems produce periodic reports that make up an organization's information support system, typically reporting measurable aspects of the organization's performance. These reports reduce uncertainty by producing information. Rules and regulations as well as procedures and standards provide a fixed, objective knowledge base from which employees can learn to respond to routine organization phenomena. Rules and regulations reduce uncertainly while equivocality is reduced before the rules and regulations are written.

\section{Methodology}

To study the practices and mechanisms for implementing risk management in a project network, a qualitative embedded single case study was conducted [37]. The case project was selected due to its complexity in terms of project participants, project environment, the unexpected events and risks, as well as the mechanisms and practices for handling those events and risks. The chosen project was a large green-field engineering project carried out in an Eastern European country. The project had a monetary value of more than 200 million USD and a lifecycle of over 5 years. The end customer was a Southern European company with permanent operations in the host country, while the turnkey contractor was a Northern European company that used various local subcontractors and two main contractors originating from the home country of the end customer. For the turnkey contractor, the project was a strategically important project in a new market area. The sales phase was fast paced and intensive. In addition, the project environment was challenging due to the unstable political situation and constant changes in regulations.

The data was collected through 10 interviews, each lasting between 50 and 180 minutes. All interviews were recorded and transcribed and were conducted with the key project individuals. The interviewees included the project directors, project managers, project team members (e.g., project engineers and controllers), as well as those in charge of risk management in the turnkey company of the project. The focus of the interviews was on the risks and unexpected events and the risk management practices to handle those risks and unexpected events. We utilised a semi-structured interview approach and all interviews were conducted informally, which encouraged the natural flow of discussion to facilitate the detailed description of the events and the risk management practices. In addition, an ethnographic interview style was used to promote in-depth and lively answers from the interviewees.

The transcribed interview content was carefully analysed to identify relevant practices of risk management as well as prevailing circumstances. Perceived information processing mechanisms to handle unexpected events and risks were categorized based on the framework introduced by Daft and Lengel [12] as those being formal and those being informal by their nature. The different mechanisms were collated in an Excel sheet, empirical 
examples of the different risk mechanisms were identified from the transcribed interviews, and the implications of the employed mechanisms and fitness within the contextual situation were listed alongside quotations for each mechanism.

\section{Empirical Findings}

In the interviews, the practices and mechanisms for implementing risk management in the large engineering project during its sales and delivery phase were studied. The engineering project was executed by a complex project network of global companies in a challenging project environment. The host country of the project was a new environment for the turnkey contractor and it was not the home country of the end customer. The main contractors and their subcontractors did not have previous relationships with the turnkey contractor. The host country was an Eastern European country with instable political and institutional frameworks. The sales phase of the turnkey contractor's project was short and intensive. The turnkey contractor made a strategic decision to corner a new market area, which led to some overly optimistic promises during the sales phase. We found evidence that risk management was carried out partly as integrated functions of the sales and project phases and partly as formally structured, dedicated actions.

Based on the content analysis, several practices and mechanisms for implementing risk management in the project network were identified. Perceived practices and mechanisms are categorized according to the mechanisms introduced by Daft and Lengel [12] to reduce uncertainty and equivocality. Company rules and criteria, specifications, formal risk sheets, progress follow-up tools, special reporting systems, as well as common database and project plans were recognized as formal information processing mechanisms to reduce uncertainty in the project network. Personal relationships, direct contact, personal commitment and special face-face meetings were identified as informal mechanisms to reduce equivocality. The identified practices and mechanisms for implementing risk management in the case project network are presented in Table 1.

\subsection{The Use of Formal Practices and Mechanisms}

Based on the analysis, it appears that different kinds of predefined formal practices and mechanisms were used during the sales and project phases to gather information about the project participants and the project environment in order to enhance project risk management. As a global project-based company, the turnkey contractor had company rules and criteria for supplier selection, contract drafting and formal risk management practices to be implemented in projects. The selection of one particular main contractor was a part of the deal with the end customer, hence not all standard rules were followed in the subcontractor selection process. The main contractors and the subcontractors were previously unknown to the turnkey contractor and so the turnkey contractor was not aware of the behaviour of the contractors in case of difficulties. The payment terms in the contract between the turnkey contractor and the main contractors were specified so that, when the end customer delayed their payments to the turnkey contractor, the main contractors did not get their payments but were instead forced to finance the project. Negative cash flow caused financial problems for the main contractors and they were nearly bankrupt. Although the turnkey contractor had good contracts with their subcontractors, they had to renegotiate many contracts to be able to continue the project, as illustrated in a quotation from the project director of the turnkey contractor:

"Contract terms were good and solid for us. But it did not work at all in practice. Guys of the contractors did not have money to buy erection materials. We had to change the contract terms and then it started to work. There were approximately twenty contracts which we negotiated again."

One company rule of the turnkey contractor as a formal practice of project risk management was the specification in the contract of the responsibilities of the project parties. This rule was not strictly followed but some vague specifications existed. When disputes about the responsibilities occurred, the contract could not provide a solid basis for the resolution and so the responsibilities had to be partly renegotiated by the project parties. The project director of the turnkey contractor describes the role of specification of the responsibilities as a risk management practice as follows:

"We [turnkey contractor] have contracts with our customer and our contractors. The best way to manage risks is to have solid and watertight specification of the responsibilities. So when you have a dispute with the customer or with the contractors regarding extra costs you can show the contract and say: 'Look at the contract, it is specified here'." 
Table 1. Categorized practices for implementing risk management in the case project.

\begin{tabular}{|l|lrl}
\hline \multicolumn{3}{|c}{ Practices for Implementing Risk Management in the Project Network } \\
$\begin{array}{l}\text { Mechanism } \\
\text { category }\end{array}$ Mechanism & $\begin{array}{l}\text { Mechanisms in } \\
\text { the case project }\end{array}$ & $\begin{array}{c}\text { Application of the mechanisms } \\
\text { in the case project }\end{array}$ & $\begin{array}{c}\text { The implications of the employed } \\
\text { mechanisms and fitness } \\
\text { with the contextual situation }\end{array}$ \\
\hline
\end{tabular}

The subcontractors had to carry the risk of financing the project when the turnkey contractor delayed their payments. In the unknown environment, the turnkey

Company rules for the selection of subcontractors were not strictly followed

Established rules (e.g. financial situation of the potential and criteria for the subcontractors was not checked thoroughly selection of before signing the contract). In addition, subcontractors the turnkey contractor had to select one main at a global level. subcontractor as a part of the contract with the end customer, hence the evaluation of the main subcontractor was incomplete.

Specification of responsibilities in the contract.

Formal risk sheet. of the subcontractors' capability before subcontractor selection (the second ground of subcontractor selection after the project was delayed) and (2) identification and evaluation of risks of the project during the sales phase and in the project execution phase.

Progress

follow-up tool.

The actual progress of the turnkey contractor was followed-up with a formal tool.

Database for project information.

Project data was available in the global database for employees of the turnkey contractor. contractor was not aware of the behavior of the subcontractors. The weak financial situation of the subcontractors caused a delay in the project. If strictly followed, rules and criteria would have been suitable mechanisms to reduce uncertainty but rules and criteria would also have some weaknesses related to the situations of high equivocality due to the complex project network and unstable project environment.

When a dispute occurred, it was not possible to refer to the contract due to it not clearly specifying responsibilities. Project parties had to negotiate the responsibilities again. Standard rules would have been a comprehensive practice to avoid risk related to the lack of information in terms of specification.

The selected subcontractors had the manpower to fulfill their obligations. Some risks were identified and managed well with the formal risk sheets. The delay caused by the prolonged permitting process was not identified as a risk during the sales phase or the project execution phase. Company rules were not strictly followed in terms of regular updating of the risk sheet during the project phase. The formal risk sheet was an appropriate practice which reduced uncertainty but it also had some weaknesses related to high equivocality due to the complex project network and unstable project environment.

The turnkey contractor was able to follow-up the actual progress of its entire project scope. The formal follow-up tool was a comprehensive/appropriate practice to gather information and reduce uncertainty. However, the usability of the tool requires that rules are strictly followed in terms of accuracy of the information.

The project database was a suitable practice to gather information and reduce uncertainty.

The end customer was able to review the status of the turnkey contractor's entire project scope by having access to the same follow-up tool which the turnkey contractor used. This was a comprehensive approach for reporting purpose and to reduce uncertainty. 


\section{Continued} after the project was delayed.

Start-up team/country study team.
Updated project plan

Progress of permitting

(main cause of delay) was followed up with a special report.

A project plan which described all of the remaining main steps and activities of the project was prepared to provide an overview of the entire project.

Country specific information and knowledge was gathered and forwarded to the project team. The start-up team also established practices and contacts with local project stakeholders and participants.

The turnkey contractor's project manager

Personal relationships between the

No. 4 managed to establish good and trusting personal relationships with the end customer. The turnkey contractor's

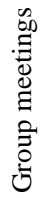
turnkey contractor and the customer.

Personal relationships between the turnkey contractor and the main contractor. the turnkey contractor and subcontractors for the evaluation of subcontractors'

The turnkey contractor changed subcontractors and evaluated new
potential subcontractors in the capabilities in the host host country before selection. country.

Personal commitment.

Experienced individuals.

Kick-off meeting.

\section{project manager No. 3 did not have a similar sense of humor to his counterpart from the end customer.}

The turnkey contractor's project manager No. 4 managed to establish good personal relationships with its main subcontractor.

The turnkey contractor's project manager No. 2 checked all sites personally with customer.

Utilization of the experience of the turnkey contractor's individual employees during the sales phase and in the different project phases.

Lessons learned from previous projects to be introduced and discussed in the project kick-off meeting.

Face-to-face project follow-up meeting.
Due to the delay of the permitting process, a special reporting system was established to provide an overall picture of the on-line status of the permitting progress. This practice was a comprehensive and suitable means to increase information and to reduce uncertainty.

The project plan was a good and suitable practice to gather information, to obtain an overview of the situation and to reduce uncertainty.

Due to the intensive and rapid sales phase, this practice was missed and information regarding the country had to be gathered and contacts established after the project had commenced. Based on experiences with previous projects, the turnkey contractor would have received great benefit from this practice. Both uncertainty and equivocality would have been reduced with this practice.

As a consequence of good personal relationships between the turnkey contractor and the end customer, the end customer did not require penalties due to the delayed project although entitled to do so. Personal relations were important in situations where equivocality was the prevailing factor. Co-operation worked well. Personal relations were important in situations where equivocality was the prevailing factor.

The turnkey contractor received information from subcontractors and could immediately provide feedback and explain what information was required. This was a suitable approach and practice for situations where both uncertainty and equivocality were present.

Personal participation and commitment were important in situations where equivocality was the prevailing factor.

The turnkey contractor did not utilize the experience of individuals and as a consequence some risks materialized in the project. Use of the experience of individuals is a suitable approach to reduce equivocality.

Experience from previous projects was not fully utilized in the studied project. Lessons learned sessions are suitable practice for the situations where equivocality is a prevailing factor.

The turnkey contractor got to know the customer's feelings about the status and issues of the project. At the same time, the turnkey contractor built a trusting relationship with the customer. This approach was suitable for situations where equivocality was the prevailing factor. 
The turnkey contractor used a risk sheet as a formal mechanism to manage risks during the sales phase. The same risk sheet emphasizing the needs of the project execution was utilized later in the project delivery phase. Due to turbulence in the project settings, the risk sheets had to be updated regularly to keep the risk information valid and usable for the project management. Furthermore, the turnkey contractor also had a formal qualification process for supplier selection in which the capability of the supplier and risks related to their performance were evaluated following a particular predefined format.

The interviews also brought out that the progress follow-up tool and the database for the project information were used in the engineering project as formal information systems to enhance project risk management. The progress follow-up tool was used to obtain an overview of the status and progress of the entire project scope of the turnkey contractor. Data regarding current progress was gathered systematically and the picture of the entire project was as acute as the input data fed into it. A comment by the project director illustrates the importance of the validity of the data when the turnkey contractor was forced to conduct an extensive site tour to secure correct information about the status of the sites:

"We [turnkey contractor] had a site where civil works had started, materials were on site, permissions were granted etc. We followed the progress systematically but the problem was that the basic data from the site was not correct. We had a process to follow-up the progress but we could not trust in the data. As a consequence, we visited all the sites and checked the real status of each discipline."

Furthermore, the turnkey contractor had an internal database of all the project information. With the database, it was possible to share information globally with all employees. Some special reports of the turnkey contractor partly tailored for this case project were used for obtaining information about any special and important issues related to the project. The end customer had access to the turnkey contractor's progress follow-up tool and so was able to see the current status of the sites. The permitting process was vital for the progress of the entire project and so the turnkey contractor had a special report for monitoring the actual progress.

Planning as a formal practice to process information in the organization was used in the case project to enhance the project risk management process. A project plan per se is a tool of planning used to define phases and tasks to be executed during the life span of the project. In the case project, the turnkey contractor had a special practice for establishment in the host country already included in the sales phase of the project. Unfortunately, this practice was not implemented in the case project causing big difficulties, particularly in terms of the permitting process.

We observed several formal practices and mechanisms for implementing risk management in the studied engineering project. Some practices were perceived to be very appropriate and suitable for the context where uncertainty, a lack of information, was the prevailing attribute of the situation. The benefits/outcomes gained from the implementation of some practices were limited because the practices were not used in full extension or because updating was neglected or incorrect and inaccurate input data was used. In turn, based on our analysis, some informal practices (e.g. rules and criteria) did not work well in situations of equivocality.

\subsection{The Use of Informal Practices and Mechanisms}

We also identified several informal practices and mechanisms that were used in the case project to support project risk management at a network level. These practices were mainly based on direct contact between project participants as well as informal encounters. Personal relationships play a very big role in business culture in the Eastern and Southern European countries. The turnkey contractor changed their project director three times during the first two years of the project. The third project director of the turnkey contractor had difficulties maintaining personal relationships, mainly because his sense of humor differed from that of his counterpart, which impaired communication and trust building. His successor was able to create a good and embedded relationship with the representatives of the end customer, as can be seen from the following quotation:

"We [turnkey contractor] were able to establish good relationships with the end customer and they did not represent their demands for penalties although they were entitled to do so. They also gave us the contract for the second phase with reasonable terms. Our mission for the 6 months was to calm the customer so that they did not kick out us."

In the turnkey contractor's organization, much experience and established knowledge are transferred from project to project by experienced individuals. Experienced project experts provide their input during the sales phase and also in the project phase. In the case project, this opportunity to utilize experience from previous projects was partly missed, causing big problems with delays in the project. 
Group meetings as face-to-face meetings were practices used to get people together to share information, impressions and approaches. Meetings were forums for focusing on important issues and gaining a consensus on relevant topics. The interviews brought up that fact that, in the case project, face-to-face meetings were used as project kick-off meetings and special meetings with customer. The latter is illustrated in the following quotation:

"We visit the regions regularly and have meetings there with our contractors. We do not have any 'remote management system' with the slogan 'Hi, send us the report'. We are present. We also take the customer with us to the regions. We have lunch with the customer and we listen to them. We show that we appreciate them and do our best to achieve progress so that they can start to earn money with the installations. The core of the business is the satisfied customer."

Direct contacts, the use of integrators as well as group meetings, were perceived as informal practices implemented in the case project as manners of project risk management. Our data revealed that these practices were appropriate and suitable for situations where equivocality (i.e. the existence of multiple and conflicting interpretations) was present.

\subsection{Summary of Perceived Practices and Mechanisms}

The data analysis revealed many indicators of risk management mechanisms and practices in the case project network. The identified mechanisms range from formal ones based on rules and regulations as predetermined practices to informal ones such as direct contact and group meetings. We observed that some mechanisms worked very well and enhanced risk management in the entire project network. At the same time, some mechanisms were not effective as risk management practices in the case project. We found evidence that the ineffectiveness was in some instances caused by not following the predefined practices and procedures, while in some cases it was caused by the unsuitability of the mechanism to the prevailing contextual situation. Some formal mechanisms, established rules and criteria as well as formal risk sheets, were perceived to be inefficient in situations of high equivocality. This finding is consistent with information processing theory's notion that formal mechanisms should be used in the situations of uncertainty and informal mechanisms in the situations of high equivocality.

\section{Discussion and Conclusions}

The results of this study contribute to research on risk management in project networks, which has not been widely studied previously [38] [39]. In this paper, information processing mechanisms for implementing risk management in project networks were studied in the sales and project delivery phases. Based on our analyses, we observed eight different formal mechanisms which supported project network level risk management in the case project network. These mechanisms are (1) established rules and criteria for the selection of subcontractors at a global level, (2) specification of responsibilities in the contract, (3) formal risk sheet, (4) progress follow-up tool, (5) database for project information, (6) customer reporting system, (7) updated project plan after the project was delayed, and (8) start-up team/country study team. These perceived mechanisms are akin to the ones introduced by Daft and Lengel [12] as formal mechanisms to reduce uncertainty. Personal relationships between parties, personal commitment, experienced individuals, and face-to-face meetings were identified as informal information processing mechanisms used as measures of project risk management to reduce equivocality. In our study we also elaborated the fitness of the chosen mechanisms for the contextual situation and our analysis reveals that the use of rules and criteria as well as formal risk sheets as formal information processing practices had some weaknesses in situations where equivocality (the existence of multiple and conflicting interpretations) was the dominant feature. One challenge to the usability of the mechanism for risk management is the regular updating necessary due to continuous changes in the project set-up and environment. In this study, we analysed project risk management at the project network level from the information processing perspective, which provides a novel perspective for project risk management theorizing. The contribution of this study to the literature concerning project risk management is to show how informal risk management practices in addition to formal practices should be considered, particularly in the context of equivocality as the dominant feature of circumstances.

\section{Managerial Implications}

The findings of this research have various managerial implications. The study introduces several tools and prac- 
tices to be implemented in international project networks to enhance project risk management. The findings of the study suggest that managers should pay attention to the selection of risk management practices based on the contextual features of the situations. Formal information processing practices should be selected in cases where uncertainty (lack of information) is the prevailing feature and informal practices should be selected for situations where equivocality (the existence of multiple and conflicting interpretations) is the dominant contextual feature. Some challenges of the risk management from the point of view of practice implementation are presented. The limitations of this study include the analysis of only one large project network and the low number of interviews. One particularly interesting topic for further research would be to categorize risk sources with dimensions of the existence of uncertainty and equivocality. The use and effectiveness of different project risk management tools and practices for risks involving uncertainty or equivocality would also be an interesting line of research.

\section{References}

[1] Chapman, C. and Ward, S. (2003) Project Risk Management: Processes, Techniques and Insights. John Wiley \& Sons Ltd., Chichester.

[2] Miller, R. and Lessard, D. (2000) The Strategic Management of Large Engineering Projects: Shaping Institutions, Risks and Governance. MIT Press, Cambridge, MA.

[3] Ahola, T. (2009) Efficiency in Project Networks: The Role of Inter-organizational Relationships in Project Implementation. PhD Dissertation, Helsinki University of Technology, Espoo.

[4] Cova, B., Ghauri, P. and Salle, R. (2002) Project Marketing: Beyond Competitive Bidding. John Wiley \& Sons Ltd., Chichester.

[5] Engwall, M. (2003) No Project Is an Island: Linking Projects to History and Context. Research Policy, 32, 789-808. http://dx.doi.org/10.1016/S0048-7333(02)00088-4

[6] Söderlund, J. (2004) On the Broadening Scope of the Research on Projects: A Review and a Model for Analysis. International Journal of Project Management, 22, 655-667. http://dx.doi.org/10.1016/j.ijproman.2004.05.011

[7] Flyvbjerg, B., Bruzelius, N. and Rothengatter, W. (2003) Megaprojects and Risk: An Anatomy of Ambition. Cambridge University Press, Cambridge. http://dx.doi.org/10.1017/CBO9781107050891

[8] Hellgren, B. and Stjernberg, T. (1995) Design and Implementation in Major Investments-A Project Network Approach. Scandinavian Journal of Management, 11, 377-394. http://dx.doi.org/10.1016/0956-5221(95)00020-V

[9] Morris, P.W.G. and Hough, G.H. (1987) The Anatomy of Major Projects-A Study of the Reality of Project Management. John Wiley \& Sons Ltd., Chichester.

[10] Floricel, S. and Miller, R. (2001) Strategizing for Anticipated Risks and Turbulence in Large-Scale Engineering Projects. International Journal of Project Management, 19, 445-455. http://dx.doi.org/10.1016/S0263-7863(01)00047-3

[11] Pekkinen, L. (2010) Risk Management in Project Network. In: Aramo-Immonen, H., Naaranoja, M. and Toikka, T., Eds., Project Knowledge Sharing Arena, Project Management Association Finland (PMAF) in Collaboration with University Consortium of Pori (UCP) and University of Applied Sciences in Vaasa (VAMK), Espoo, 84-100.

[12] Daft, R.L. and Lengel, R.H. (1986) Organizational Information Requirements, Media Richness and Structural Design. Management Science, 32, 554-571. http://dx.doi.org/10.1287/mnsc.32.5.554

[13] Kähkönen, K. and Artto, K. (2008) Concepts and Processes. In: Kähkönen, K., Artto, K., Karjalainen, J., Martinsuo, M. and Poskela, J., Eds., Management of Uncertainty, Helsinki University of Technology, Helsinki, 8-23.

[14] Artto, K. and Kujala, J. (2008) Project Business as a Research Field. International Journal of Managing Projects in Business, 1, 469-497. http://dx.doi.org/10.1108/17538370810906219

[15] Ward, S. and Chapman, C. (2003) Transforming Project Risk Management into Project Uncertainty Management. International journal of Project Management, 21, 97-105. http://dx.doi.org/10.1016/S0263-7863(01)00080-1

[16] Perminova, O., Gustafsson, M. and Wikström, K. (2008) Defining Uncertainty in Projects-A New Perspective. International Journal of Project Management, 26, 73-79. http://dx.doi.org/10.1016/j.ijproman.2007.08.005

[17] Ward, S. and Chapman, C. (2004) Making Risk Management More Effective. In: Morris, P. and Pinto, J., Eds., Wiley Guide to Managing Projects, John Wiley \& Sons, Chichester, 852-875.

[18] APM (2006) APM Body of Knowledge. 5th Edition, Association for Project Management, Princes Risborough.

[19] PMI (2008) A Guide to the Project Management Book of Knowledge (PMBOK). 4th Edition, Project Management Institute, Newtown Square.

[20] Artto, K., Eloranta, K. and Kujala, J. (2008) Subcontractors’ Business Relationships as Risk Sources in Project Networks. International Journal of Managing Projects in Business, 1, 88-105. 
http://dx.doi.org/10.1108/17538370810846432

[21] Hallikas, J., Virolainen, V.M. and Tuominen, M. (2002) Risk Analysis and Assessment in Network Environment: A Dyadic Case Study. International Journal of Production Economics, 78, 45-55. http://dx.doi.org/10.1016/S0925-5273(01)00098-6

[22] Ward, S. (1999) Requirements for an Effective Project Risk Management Process. Project Management Journal, 30, 37-43.

[23] Raz, T., Shenhar, A. and Dvir, D. (2002) Risk Management, Project Success, and Technological Uncertainty. R\&D Management, 32, 101-109. http://dx.doi.org/10.1111/1467-9310.00243

[24] Cova, B. and Salle, R. (2005) Six Key Points to Merge Project Marketing into Project Management. International Journal of Project Management, 23, 354-359. http://dx.doi.org/10.1016/j.ijproman.2005.01.006

[25] Skaates, M.A. and Tikkanen, H. (2003) International Project Marketing: An Introduction to the INPM Approach. International Journal of Project Management, 21, 503-510. http://dx.doi.org/10.1016/S0263-7863(02)00021-2

[26] Kharbanda, O.P. and Stallworthy, E.A. (1983) How to Learn from Project Disasters: True-Life Stories with a Moral for Management. Gower Publishing Company, Hampshire.

[27] Klemetti, A. (2006) Management in Construction Project Network. Helsinki University of Technology, Report 2006/2, Helsinki.

[28] Söderholm, A. (2008) Project Management of Unexpected Events. International Journal of Project Management, 26, 80-86. http://dx.doi.org/10.1016/j.ijproman.2007.08.016

[29] Galbraith, J. (1973) Designing Complex Organizations. Addison-Wesley, Boston.

[30] Galbraith, J.R. (1974) Organization Design: An Information Processing View. Interfaces, 4, 28-36. http://dx.doi.org/10.1287/inte.4.3.28

[31] Galbraith, J.R. and Kazanjian, R.K. (1986) Organizing to Implement Strategies of Diversity and Globalization: The Role of Matrix Designs. Human Resource Management, 25, 37-54.

[32] Martinez, J.I. and Jarillo, J.C. (1989) The Evolution of Research on Coordination Mechanisms in Multinational Corporations. Journal of International Business Studies, 20, 489-514. http://dx.doi.org/10.1057/palgrave.jibs.8490370

[33] Tushman, M. and Nadler, D. (1978) Information Processing as an Integrating Concept in Organizational Design. Academy of Management. The Academy of Management Review, 3, 613-624.

[34] Prencipe, A. and Tell, F. (2001) Inter-Project Learning: Processes and Outcomes of Knowledge Codification in Project-Based Firms. Research Policy, 30, 1373-1394. http://dx.doi.org/10.1016/S0048-7333(01)00157-3

[35] Hobday, M. (2000) The Project-Based Organisation: An Ideal form for Managing Complex Products and Systems? Research Policy, 29, 871-893. http://dx.doi.org/10.1016/S0048-7333(00)00110-4

[36] DeFillippi, R.J. (2002) Organizational Models for Collaboration in the New Economy. Human Resource Planning, 25, 7-18.

[37] Yin, R. (2002) Case Study Research. Sage, Thousand Oaks.

[38] Lehtiranta, L. (2014) Risk Perceptions and Approaches in Multi-Organizations: A Research Review 2000-2012. International Journal of Project Management, 32, 640-653. http://dx.doi.org/10.1016/j.jproman.2013.09.002

[39] Tukiainen, S., Aaltonen, K. and Murtonen, M. (2010) Coping with an Unexpected Event: Project Manager’s Contrasting Sensemaking in a Stakeholder Conflict in China. International Journal of Managing Projects in Business, 3, 526543. http://dx.doi.org/10.1108/17538371011056129 
Scientific Research Publishing (SCIRP) is one of the largest Open Access journal publishers. It is currently publishing more than 200 open access, online, peer-reviewed journals covering a wide range of academic disciplines. SCIRP serves the worldwide academic communities and contributes to the progress and application of science with its publication.

Other selected journals from SCIRP are listed as below. Submit your manuscript to us via either submit@scirp.org or Online Submission Portal.
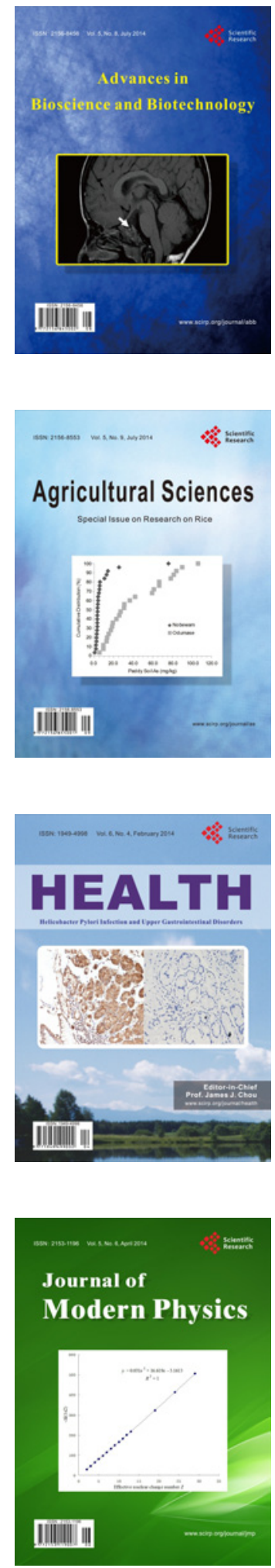
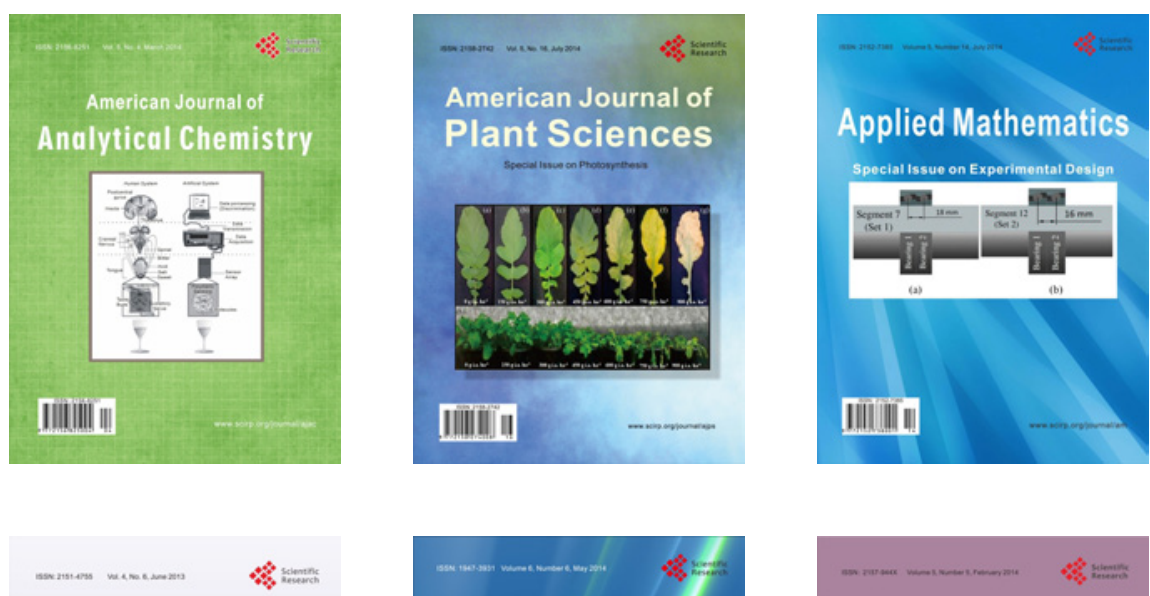

Creative Education
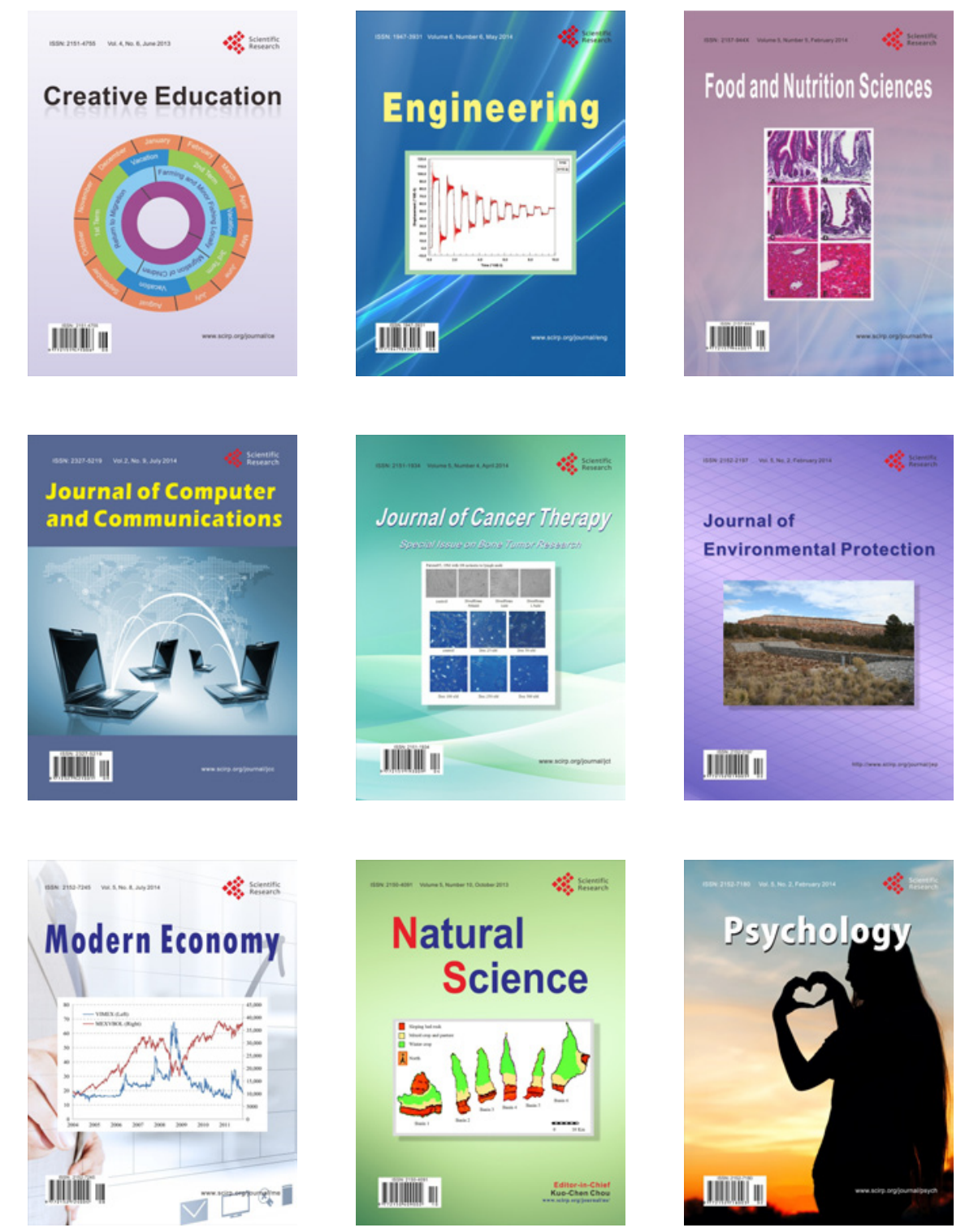